\title{
An uncomplicated and safe technique for preventing endotracheal tube cuff damage during tracheostomy using pressure-controlled ventilation: the PCV method
}

\author{
Yuki Kojima, DDS, PhD • Takeshi Murouchi, MD, PhD • Mitsutaka Sugimura, DDS, PhD
}

Received: 20 July 2020/Revised: 28 July 2020/Accepted: 30 July 2020/Published online: 10 August 2020

(C) The Author(s) 2020

\section{To the Editor,}

The coronavirus is spread primarily via respiratory droplets and close or direct contact. Aerosol propagation is also possible through prolonged exposure to high concentrations of infected aerosols in a relatively closed environment. ${ }^{1}$ According to recently reported data, at least $10 \%$ of patients with coronavirus disease (COVID-19) required hospitalization in critical care units, and approximately $3 \%$ required mechanical ventilation through an endotracheal tube (ETT) during the course of illness. $^{2,3}$ Many patients who require mechanical ventilation will later need to undergo tracheostomy. Tracheostomy is associated with an increased production of aerosols and a higher risk of viral transmission to healthcare personnel. ${ }^{4}$ Herein, we describe a safe technique for tracheostomy that is applicable for patients with COVID-19, with an emphasis on the safety of both the patient and the medical team involved. ${ }^{5}$ We have termed this technique the "pressure-controlled ventilation" (PCV) method.

From the perspective of aerosol prevention, tracheostomy is better performed after intubation under general anesthesia than in an awake patient with spontaneous breathing. The most frequent complication

\footnotetext{
Y. Kojima, DDS, PhD ( $₫) \cdot$ M. Sugimura, DDS, PhD Department of Dental Anesthesiology, Field of Oral and Maxillofacial Rehabilitation, Kagoshima University Graduate School of Medical and Dental Sciences, Kagoshima, Japan e-mail: cojicoji1109@gmail.com

T. Murouchi, MD, $\mathrm{PhD}$

Department of Anesthesiology, Asahi General Hospital, Chiba, Japan
}

during a tracheostomy procedure is ETT cuff damage when the trachea is incised; this can result in ventilation difficulty and infectious aerosol dissemination. One way to prevent ETT cuff damage is to ensure that the cuff is in an optimal position-distal to the sternal notch (away from the tracheostomy incision point) but above the tracheal carina. The ETT cuff position can sometimes be confirmed by tracheal palpation; however, the relevant anterior neck structures are not always easily palpable. Moreover, if the ETT is advanced too deeply, there is a risk of endobronchial ventilation. Lastly, neck extension during tracheostomy positioning can easily move the ETT proximal to the sternal notch. As there are no reliable methods to protect the ETT cuff from damage during tracheostomy, we developed the PCV method.

The PCV method is used after performing normal intubation under general anesthesia. The ventilator is set to "pressure-controlled" mode and the patient's spontaneous breathing is temporarily suppressed using opioids or neuromuscular blocking agents. The tidal volume $\left(\mathrm{V}_{\mathrm{T}}\right)$ is checked. Next, the anesthesiologist advances the ETT until the $\mathrm{V}_{\mathrm{T}}$ decreases (by one-third to one-half) indicating that the ETT has been advanced into an endobronchial position. Once this point is reached, the ETT is slowly withdrawn until the $V_{T}$ returns to the original volume (i.e., to a position above the carina). The ETT is then secured and the tracheotomy can proceed.

In our experience, the PCV method significantly reduces the probability of ETT cuff damage and thus reduces potential aerosol generation, prevents ventilation and oxygenation difficulties if the ETT cuff is damaged, and renders the surgical procedure less difficult. Its use can theoretically reduce the risk of COVID-19 infection for respiratory care personnel, anesthesiologists, and tracheostomy surgeons. 


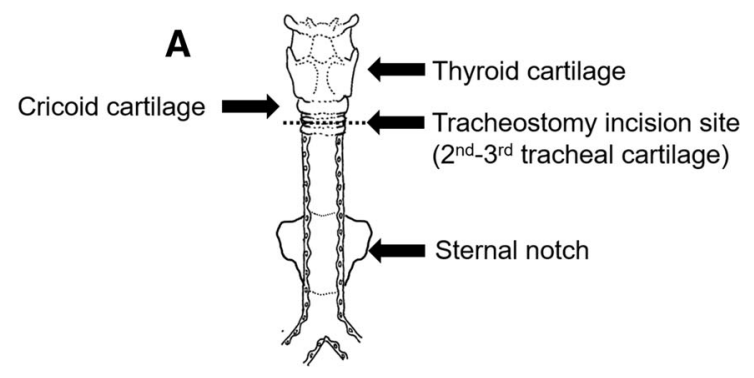

Trachea

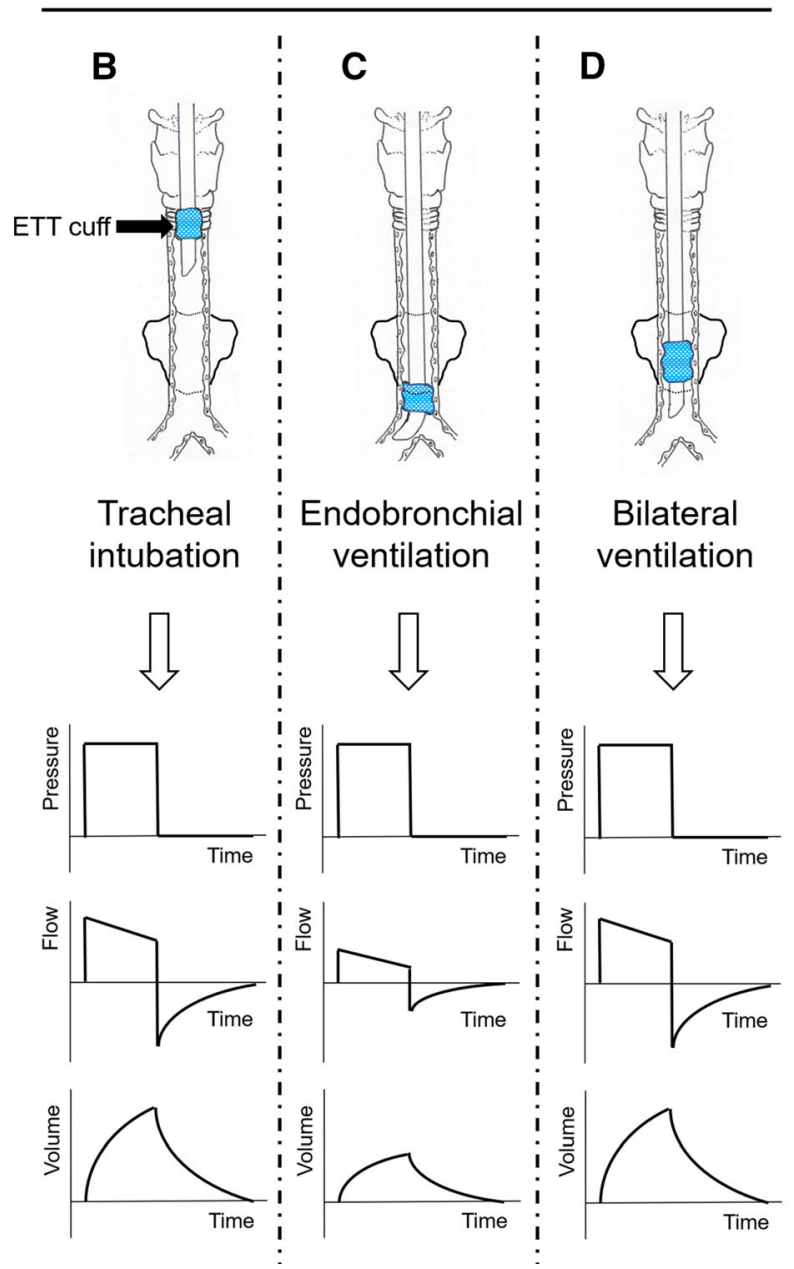

Figure A. Coronal section of the trachea. B. Endotracheal tube (ETT) intubation stage. The ventilation should be set to "pressurecontrolled." The tidal volume $\left(\mathrm{V}_{\mathrm{T}}\right)$ should be checked at this time. $\mathrm{C}$. The surgical procedure should be paused just before making the tracheal incision. The ETT should then be advanced towards the carina without changing the ventilator settings (i.e., without increasing the peak pressure). The $\mathrm{V}_{\mathrm{T}}$ is reduced as the ETT progresses beyond the carina into one of the mainstem bronchi (i.e., endobronchial position). At this time, the $\mathrm{V}_{\mathrm{T}}$ drops by approximately one third to one half. D. The ETT is then slowly withdrawn until the $\mathrm{V}_{\mathrm{T}}$ returns to the previous volume (stage $\mathrm{B}$ ). At this position, the ETT cuff should then be below the position where the incision is made. *Position of the ETT cuff is shown in blue.

\section{Disclosures None.}

Funding statement This research did not receive any specific grant from funding agencies in the public, commercial, or not-for-profit sectors.

Editorial responsibility This submission was handled by Dr. Hilary P. Grocott, Editor-in-Chief, Canadian Journal of Anesthesia.

Open Access This article is licensed under a Creative Commons Attribution-NonCommercial 4.0 International License, which permits any non-commercial use, sharing, adaptation, distribution and reproduction in any medium or format, as long as you give appropriate credit to the original author(s) and the source, provide a link to the Creative Commons licence, and indicate if changes were made. The images or other third party material in this article are included in the article's Creative Commons licence, unless indicated otherwise in a credit line to the material. If material is not included in the article's Creative Commons licence and your intended use is not permitted by statutory regulation or exceeds the permitted use, you will need to obtain permission directly from the copyright holder. To view a copy of this licence, visit http://creativecommons.org/licenses/ by-nc/4.0/.

\section{References}

1. Chen X, Liu Y, Gong $Y$, et al. Perioperative management of patients infected with the novel coronavirus: recommendation from the Joint Task Force of the Chinese Society of Anesthesiology and the Chinese Association of Anesthesiologists. Anesthesiology 2020; 132: 1307-16.

2. Guan WJ, Ni ZY, Hu Y, et al. Clinical characteristics of coronavirus disease 2019 in China. N Engl J Med 2020; 382: 1708-20.

3. Meng L, Qiu H, Wan L, et al. Intubation and ventilation amid the COVID-19 outbreak: Wuhan's experience. Anesthesiology 2020; 132: $1317-32$.

4. Tran K, Cimon K, Severn M, Pessoa-Silva CL, Conly J. Aerosol generating procedures and risk of transmission of acute respiratory infections to healthcare workers: a systematic review. PLoS One 2012; DOI: https://doi.org/10.1371/journal.pone.0035797.

5. Smith D, Montagne J, Raices $M$, et al. Tracheostomy in the intensive care unit: guidelines during COVID-19 worldwide pandemic. Am J Otolaryngol 2020; DOI: https://doi.org/10.1016/ j.amjoto.2020.102578.

Publisher's Note Springer Nature remains neutral with regard to jurisdictional claims in published maps and institutional affiliations. 